\title{
ESTUDOS HISTOLÓGICOS PRELIMINARES DA MICROENXERTIA DE PLANTAS MICROPROPAGADAS DE MACIEIRA ${ }^{1}$
}

\author{
MONITA FIORI DE ABREU², JÚLIO CÉSAR DE OLIVEIRA NUNES ${ }^{3}$, MARISA SANTOS ${ }^{4}$, ENIO LUIZ PEDROTTI ${ }^{5}$
}

\begin{abstract}
RESUMO - A fruticultura moderna necessita implantar tecnologias que possibilitem a produção de frutos de alta qualidade, com custos cada vez menores. A micropropagação associada à microenxertia possibilita altas taxas de multiplicação de plantas com alta qualidade fitossanitária, além de possibilitar a realização de estudos sobre compatibilidade de enxertia em diferentes clones. O presente trabalho tem como objetivo estudar o processo de soldadura entre genótipos de macieira (Malus domestica. Borkh) multiplicadas in vitro após a microenxertia. Esta técnica foi realizada em fenda simples, sob condições assépticas. Os estudos histológicos foram realizados através de cortes longitudinais seriados de segmentos de 8 mm do ponto de enxertia. O processo de soldadura foi caracterizado pelo desenvolvimento de tecido meristemático, originando células parenquimáticas na interface do microenxerto, com a proliferação do tecido cambial da cultivar copa. Isso possibilita a ligação do sistema vascular da copa com o do porta-enxerto, resultando na sobrevivência do microenxerto.
\end{abstract}

Termos para indexação: Malus sp., micropropagação, microenxertia, histologia.

\section{PRELIMINARIES HISTOLOGICAL STUDIES FROM THE MICROGRAFTING OF TISSUE CULTURED APPLE}

ABSTRACT - The modern fruitculture needs to introduce techniques that allow a less expensive production of high quality fruits. The micropropagation associate to micrografting provides high average of plant multiplication and disease free material. In addition it provides studies of grafting compatibilities. The present work aim to study the process of the micrografting union of tissue cultured apple (Malus domestica. Borkh). The scions were cleft-grafted on the rootstocks, under aseptic conditions. For histological studies specimens were trimmed down to $4 \mathrm{~mm}$ above and below the graft union (longitudinal cuts). The graft union development resulted in the generation of meristem tissue, originating parenchymatous cells at the graft interface, and a cambial tissue proliferation from the scion. This procedure allows the vascular system connection between the scion and the rootstock, resulting on micrograft viability.

Index terms: Malus sp., micropropagation, micrografting, histology.

A cultura da macieira é uma atividade de grande importância econômica e social para o Estado de Santa Catarina. O volume de produção de maçã no Estado corresponde a mais de $50 \%$ da produção nacional (Boening, 2001). A produtividade do pomar depende do genótipo e da qualidade da muda. Nesse contexto, a micropropagação vem sendo utilizada para produção de plantas matrizes básicas, pois possibilita altas taxas de multiplicação a partir de um meristema (Nunes et al., 1999), além disso, é possível produzir em um curto período de tempo e com espaço físico reduzido (Lambardi et al., 1997).

A microenxertia consiste em enxertar um meristema, oriundo de uma planta-matriz, sobre um porta-enxerto multiplicado in vitro (Grattapaglia \& Machado, 1998). Esta técnica possibilita a detecção precoce de incompatibilidade de espécies (Prakash et al., 1999). A associação da micropropagação com a microenxertia em outras espécies hortícolas já foi utilizada por vários autores (Palma et al., 1996).

O processo de soldadura dos microenxertos é condicionado fundamentalmente pela congenialidade dos indivíduos (Dickison, 2000). O primeiro estágio da união ocorre em poucos dias. Este estágio é caracterizado pela morte de camadas celulares da interface do enxerto e pela formação de células parenquimáticas. Estas células preenchem a fenda no ponto de enxertia, constituindo o calo em associação com a região vascular da copa e do porta-enxerto (Dickison, 2000). Segundo Jeffree \& Yeoman (1983), a diferenciação de algumas células do calo, a partir de novas células cambiais, forma uma união entre os tecidos afins da copa e do porta-enxerto, resultando no estabelecimento de uma conexão cambial contínua. Estes autores ressaltam que o posterior desenvolvimento da copa pelo alongamento e formação de novas camadas celulares assegura o estabelecimento da continuidade da vascularização entre o porta-enxerto e a copa.

Moore \& Walker (1983) observaram que, na ausência da diferenciação vascular, o calo adjacente promove a soldadura entre os tecidos. Com base nestes dados, Prakash et al. (1999) constataram que a fase final da soldadura, na qual ocorreria a rediferenciação do tecido vascular através da interface do enxerto, não é absolutamente essencial para o sucesso da enxertia. Os trabalhos encontrados na bibliografia disponível não são suficientes para confirmar este fato; por este motivo, o presente trabalho objetivou descrever as características histológicas do processo de soldadura entre plantas de macieira micropropagadas e microenxertadas.

Para este estudo, foram utilizadas plântulas, oriundas de micropropagação, da cultivar copa Gala (Malus domestica B.) e dos porta-enxertos de macieira M9 (Malus pumilla) e Marubakaido (Malus prunifolia), com cerca de $9 \mathrm{~cm}$. A enxertia foi em fenda simples (Hartmann et al., 1990), realizada 25 dias após a repicagem em meio de cultura. Os microenxertos foram inoculados em frascos com meio de cultura MS (Murashige \& Skoog, 1962) e transferidos para a sala de crescimento, com temperatura de $24 \pm 2^{\circ} \mathrm{C}$, fotoperíodo de 16 horas e luminosidade de $30 \mu \mathrm{mol} . \mathrm{m}^{-2} . \mathrm{s}^{-1}$, onde permaneceram até as coletas dos segmentos.

Para os estudos histológicos, de ambas as combinações enxertoporta-enxerto, Gala sobre Marubakaido e Gala sobre M9, foram realizadas 120 microenxertias (60 para cada combinação). Foram retirados segmentos de $8 \mathrm{~mm}$ de comprimento do ponto de enxertia, tamanho correspondente ao da fenda realizada para o processo de microenxertia. O material vegetal coletado foi fixado em FAA (formaldeído: ácido acético: etanol 50\%; 5:5:90), desidratado em série etílica e emblocado em parafina (Johansen, 1940). Os segmentos foram posicionados para que os cortes longitudinais fossem realizados de forma paralela à orientação da enxertia, possibilitando a visualização completa do processo de soldadura. Os cortes, com $10 \mu \mathrm{m}$ de espessura, feitos em micrótomo de rotação, foram corados com safranina e fast-green e montados, entre lâmina e lamínula, com bálsamo do Canadá. A análise de cerca de 150 cortes histológicos foi feita em microscopia óptica.

A análise do material revelou que, 30 dias após a microenxertia, ocorreu a soldadura parcial dos microenxertos. Foram observadas células meristemáticas cambiais na copa, próximas à interface do enxerto, penetrando no porta-enxerto. Algumas destas células ainda são indiferenciadas e outras já se caracterizam como parenquimáticas ou vasculares jovens. Tais observações indicam a potencialidade deste tecido meristemático para gerar novos elementos vasculares, que possi-

\footnotetext{
${ }^{1}$ Trabalho (084/2002). Recebido: 06/05/2002 ; Aceito para publicação: 13/02/2003.

${ }^{2}$ Bolsista PIBIC/BIP/CNPq/UFSC, Graduanda em Agronomia, CCA/UFSC. Caixa postal 476 CEP:88040 -970, Florianópolis, SC. e-mail: monitaf@yahoo.com. ${ }^{3}$ Eng. Agr ${ }^{\circ}$, M.Sc, Embrapa Caixa postal 317 CEP:89460 -000, Canoinhas, SC. e-mail: jconunes@yahoo.com.br.

${ }^{4}$ Bióloga, Professor Dr., Departamento de Botânica, CCB/UFSC Campus Universitário CEP:88040 -900, Florianópolis, SC. e-mail: marint@mbox1.ufsc.br. ${ }^{5}$ Eng. Agr ${ }^{\circ}$, Professor Dr., Departamento de Fitotecnia, CCA/UFSC. Caixa postal 476 CEP:88040 -970, Florianópolis, SC. e-mail: pedrotti@cca.ufsc.br.
} 
bilitam a conexão vascular entre a copa e o porta-enxerto. O estabelecimento completo de uma conexão cambial contínua, como observado por Jeffree \& Yeoman (1983), não pode ser verificado, mas com base nas evidências constatadas, isto provavelmente ocorreria num período de tempo maior do que o de 30 dias, utilizado para este estudo.
Estudos mais detalhados, durante todo o processo de soldadura de microenxertos, deverão ser conduzidos, visando a aprofundar o conhecimento sobre compatibilidade e incompatibilidade entre genótipos utilizados para produção comercial de espécies frutíferas.

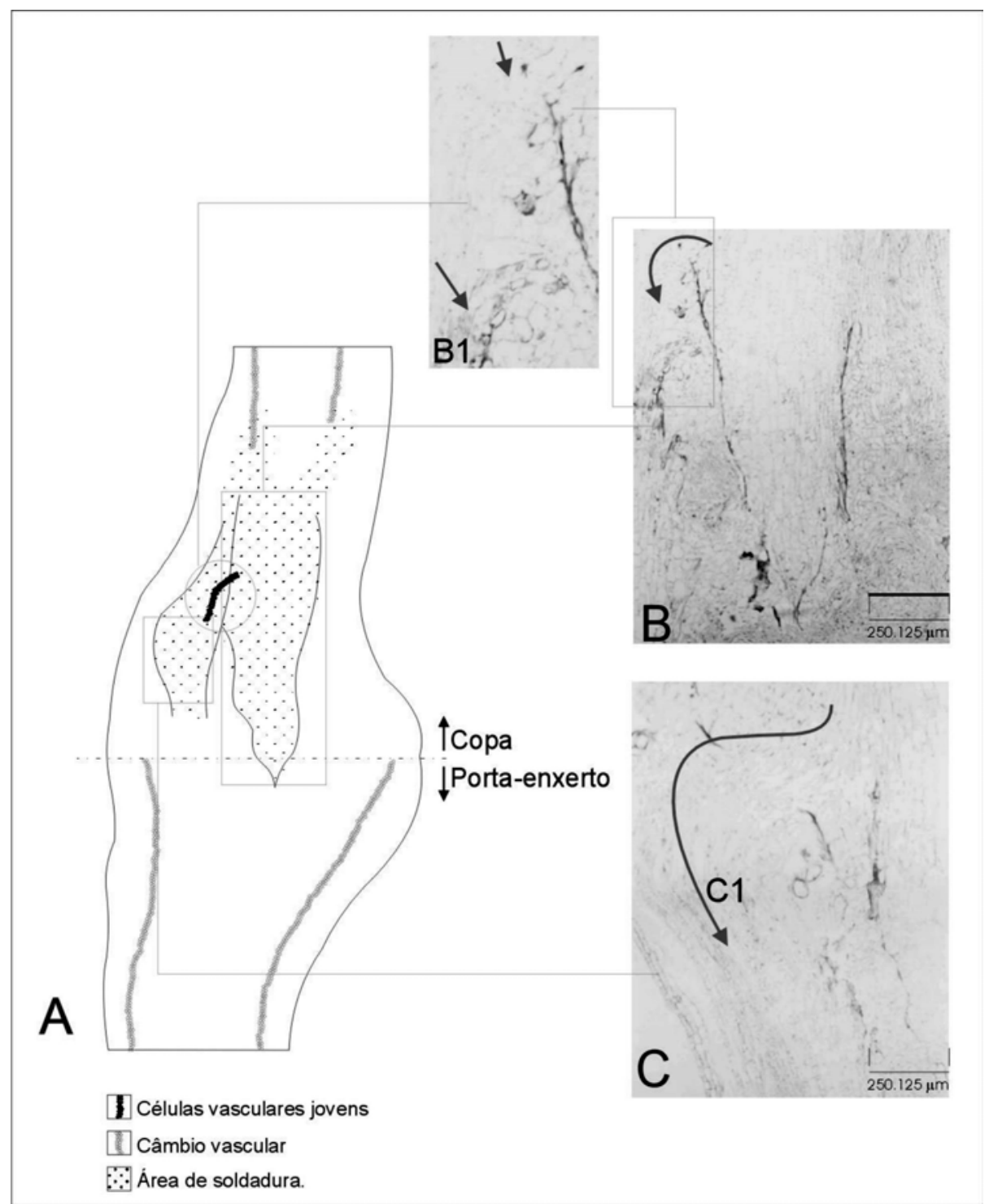

FIGURA 1- Microenxertia de macieira (Malus spp.). A. Esquema da fenda simples da microenxertia e atividade celular do processo de soldadura. Tecido meristemático, presença de células indiferenciadas e células parenquimáticas B. Cunha formada pela fenda da microenxertia. B1. Detalhe da produção de células vasculares jovens formadas na interface do enxerto. C. Detalhe de células da copa penetrando no porta-enxerto. C1. Direcionamento das células da copa na área de soldadura.

\section{REFERÊNCIAS BIBLIOGRÁFICAS}

BOEING, G. Síntese Anual da Agricultura de Santa Catarina 2000-2001. Florianópolis: Instituto de Planejamento e Economia Agrícola de Santa Catarina, 2001, p.65-67.

DICKISON, W.C. Integrative plant anatomy.: Hartcourt: Academy Press, 2000.533p.

GRATTAPAGLIA, D.; MACHADO, M.A. In.: TORRES, A.C.; CALDAS, L.S.; BUSO, J.A. Cultura de tecidos e transformação genética de plantas. Brasília: ABCTP/EMBRAPA, 1998. v.1, p. 183-260.

HARTMANN, H.T.; KESTER, D.E.; DAVIES JR., F.T.D. Plant propagation: Principles and Practices. 5.ed. New Jersey: Prentice Hall, Englewood Cliffs, 1990. p.305-312.

JEFFREE, C.E.; YEOMAN, M.M. Development of intercellular connections between opposing cells in graft unions. New Phytologist, New York, v.93, n.4, p.491-509, 1983.

JOHANSEN, D.A.. Plant microtechnique. New York: McGraw Hill Book Company, 1940. 523p.

LAMBARDI, M.; BENELLI, C.; FABBRI, A. In vitro axillary shoot proliferation of apple rootstocks under different ethylene conditions. In vitro cellular \& Developmental Biology-Plant, Columbia, v.33, n.1, p.70-74, 1997.

MOORE, R.; WALKER, D.B. Studies of vegetative compatibility-incompatibility in higher plants, VI. Grafting of Sedum and Solanum callus tissue in vitro. Protoplasma, Wien, v.115, p.114-121, 1983.

MURASHIGUE, T. E.; SKOOG, F. A revised medium for rapid growth and bioassay with tobacco tissue cultures. Physiology Plantarum, Wageningen v.15, p.473-479, 1962.

NUNES, J.C.O.; BARPP, A.; SILVA, F.C.; PEDROTTI, E.L. Micropropagação do porta-enxerto 'Marubakaido' (Malus prunifolia), a partir da cultura de meristemas. Revista Brasileira de Fruticultura, Jaboticabal, v.21, n.2, p.191-195, 1999.

PALMA, B.; VOGT, G.F.; NEVILLE, P. A combined in vitro/in vivo method for improved grafting of Acacia senegal L. willd. Journal of Horticultural Science, Cambrige, v.3, n.71, p.379-381, 1996

PRAKASH, O.; SOOD, A.; SHARMA, M.; AHUJA, P.S. Grafting micropropagated tea [Camellia sinensis (L.) O. Kuntze] shoots on tea seedlings - a new approach to tea propagation. Plant Cell Reports, Berlin, v.18, p.883-888, 1999. 